\title{
IMPROVING THE STUDENTS ABILITY AT WRITING DESCRIPTIVE TEXTS BY USING THE LEARNING CELL LEARNING STRATEGY AT GRADE X-FASHION STUDY PROGRAM AT SMK N 2 KOTANOPAN
}

\author{
By \\ Dina Syarifah Nasution \\ Sekolah Tinggi Agama Islam Negeri Mandailing Natal \\ Email: dinasyarifah1982@gmail.com
}

\begin{tabular}{l}
\hline Article Info \\
\hline Article history: \\
Received Mei 18, 2021 \\
Revised June 23, 2021 \\
Accepted July 29, 2021 \\
\hline
\end{tabular}

\section{Keywords:}

Learning cell strategy

Descriptive texts

Students abiity

Fashion study program

\begin{abstract}
This research aims to measure the implementation of the learning cell learning strategy on improving students` ability at writing descriptive texts of grade $\mathrm{x}$ - fashion study program at SMK N 2 Kotanopan, Mandailing Natal-Sumatera Utara. The method of this research was classroom action research. The participants in this classroom action research were 21 students of grade $\mathrm{x}$ - fashion study program SMK N 2 Kotanopan. The instrument consisted of the learning cell learning strategy, writing test, observation sheet, and interviews. The data of this research was analyzed two methods of data analysis.Quantitative data analysis was used to examining and interpreting data from the learning cell learning strategy and writing test.The data taken from observation and interview was used qualitative data analysis.the result shows that the learning cell learning strategy better improves the students`ability at writing descriptive texts. This can be evidence from the students mean which improved gradually in the first cycle and second cycle that there was significance value on students` marks at writing descriptive texts through the learning cell learning strategy. The mean of pre-test was 61, 04, the mean of post-test in first cycle was 74, 23 and the mean of post-test in second cycle was 82,80 . The percentage of the students score in pre-test who got point up to 75 there were only 2 of 21 students $(9,52 \%)$, and percentage of the student's score in the cycle I who got point up 75 there were only 8 of 21 students $(38,09 \%)$. It means that there was an improvement of about $28,57 \%$. Then the percentage of the student's score in post-test of the second cycle who got a point up 75 there were 19 of 21 students $(90,47 \%)$. It meant the improvement was $80,95 \%$ from the pretest.
\end{abstract}

This is an open access article under the CC BY-SA license.

\section{Corresponding Author:}

Dina Syarifah Nasution

Sekolah Tinggi Agama Islam Negeri, Mandailing Natal

Email: dinasyarifah1982@gmail.com

\section{INTRODUCTION}

In English language, there are four skills to be mastered, They are listening, speaking, reading and writing. Writing is how to produce a written product. It is a process of transforming ideas coherently and cohesively into written text. In writing skill, there are some kinds of text that will be learned by the students, one of them is descriptive text. Descriptive text is a kind of text that is used to describe something. It is usually used to describe a thing, person, place or event to give an explanation for someone. 
There are many factors that can influence the low of student's ability at writing descriptive text, such as internally and externally. Internally consist of motivation, interest, personality, element language, etc. externally consist of teacher's ability, facility of school, learning media include learning strategy.

Learning strategy can be defined as the general patterns of activities of teachers and students in the embodiment of teaching and learning activities to achieve the objectives that have been outlined.

Ideally, if the teacher can be applying the learning strategy which matches with the student's situation, it can make the student more interested and will improve their ability in mastering a learning material. In fact,writing is not easy for the Grade X- Fashion Study Program at SMK N 2 Kota Nopan.The students of grade X- Fashion Study Program got difficulties in writing tests, especially doing describing objects, although they had been given the explicit background knowledge about descriptive texts.

This problem happened because the students have difficulties writing descriptive text. Besides that, the teacher always uses conventional methods, so that the students have less interest that affects their ability at writing descriptive text.

Therefore to solve the problems above, the writer proposes using a learning strategy like the learning cell learning strategy. The learning cell is an effective way for a pair of students to study and learn together. Furthermore, this strategy is hoped to be able to increase the student's ability at writing descriptive text. Besides that, students can be more active and open their opportunities in the way of thinking in learning.

The definition of writing has several meanings. According to Jhon Langan in his book, writing is treated as a process. This means that when you first write something down, you have already been thinking about what you are going to say and how you are going to say it. Then after you have finished writing, you read over what you have written and make changes and corrections. Therefore, writing is never a one-step action; it is a process that has several steps.

Writing is both a physical and a mental act. At the most basic level, writing is the physical act of committing words or ideas to some medium, whether it is hieroglyphics inked onto parchment or an email message typed into a computer. On the other hand, writing is the mental work of inventing ideas, thinking about how to express them, and organizing them into statements and paragraphs that will be clear to a reader.

Writing, one of the world's oldest technologies, uses an expansive array of tools, from pencil or pen to software programs and video streaming capacities.6

According to Utami Dewi in her book, that writing is the expression of language in the form of letters, symbols, or words.It means that someone can express what are there in their mind by using letter, symbol, or words that can be understood by the reader as a manifestation from their mind.

There are many kinds of text types in writing such as narrative text, recount text, new items, procedure text, descriptive text, report text, analytical exposition, spoof text, hortatory exposition, explanation text, discussion text, review text, anecdote text.

\section{RESEARCH METHOD}

This research was a Classroom Action Research. According to Wallace (1998), a Classroom Action Research is a research which focuses to facilitate the reflective cycle and this way provides an effective method for improving professional action. It means that a classroom action research is conducted to improve and solve the problems that occur in the classroom. Besides that, it also increases the students' quality in learning process. The researcher found the students in his classroom have a problem in speaking skill. The researcher considered that CAR is conducted to help her to solve the problems that occurred in the classroom. Based on the statement above the researcher can conclude that classroom action research is one of ways to solve teaching problem in a form of action which done in the class. In this case, she was helped by English teacher called a collaborator. There are some steps that researcher should know if they want to conduct the action research. Kemmis and Taggart (1988: 10)state that there are four fundamentals steps of action research; they are plan, action, observation and reflection. In this research the researcher planned to conduct one cycle design only. But, because the result was still not satisfactory, the second cycle was conducted. The participants of this research were the researcher, collaborator and 44 students at grade XFashion Study Program of SMKN N 2 Kota Nopan got difficulties in writing of Descriptive Texts. So the researcher thought that it is much better if she helped the students to improve their skill in writing of descriptive texts using the learning cell-learning strategy. The data in the research were gathered from: (1) observation checklists on students, teacher, and steps of teaching, (2) fields notes,(3) interviews and (4) writing test.

\section{RESULTS AND ANALYSIS}


International Journal of Social Science (IJSS)

Vol.1 No.2 August 2021, pp: 105-114

ISSN: 2798-3463 (Printed) | 2798-4079 (Online)

DOI: https://doi.org/10.53625/ijss.v1i2.143

There are two different kinds of data; quantitative and qualitative data gathered in the research. The findings are important to answer questions of the research. The quantitative data gathered in the research is aimed to answer whether the learning cell-learning strategy of Descriptive Texts could improve the teaching and learning process in teaching writing at grade X-Fashion Study Program of SMKN 2 Kota Nopan .While the qualitative data answered the second question about what factors influence the improvement of students `writing skills of Descriptive Texts at grade X-Fashion Study Program of SMKN 2 Kota Nopan.

First Cycle

The writer is conducting based on the problems that was found in the pretest. In the pre-test, it was found that the students are difficult to write descriptive text and even they don't know to produce it, cycle I was conducted from meeting 1 until meeting 2 .

Table 1. Action for showing the learning cell learning strategy

\begin{tabular}{cll}
\hline No & \multicolumn{1}{c}{ Activities } & \multicolumn{1}{c}{ Output } \\
\hline 1 & $\begin{array}{l}\text { Conducting test before doing cycle I } \\
\text { (pre test) }\end{array}$ & $\begin{array}{l}\text { Knowing the student's writing } \\
\text { descriptive text ability before giving } \\
\text { the material }\end{array}$ \\
2 & $\begin{array}{l}\text { Explain the material and competence } \\
\text { which will reached }\end{array}$ & $\begin{array}{l}\text { Students will know the material and } \\
\text { competence so that will encourage } \\
\text { them focus }\end{array}$ \\
3 & $\begin{array}{l}\text { Giving the instruction how to apply } \\
\text { The learning cell strategy }\end{array}$ & $\begin{array}{l}\text { Knowing the procedures/ steps of the } \\
\text { learning cell strategy } \\
\text { Knowing the improvement of their } \\
\text { writing descriptive texts }\end{array}$ \\
& $\begin{array}{l}\text { Conducti ng the assesment during } \\
\text { cycle 1 by asking the students to } \\
\text { writing based on the picture by }\end{array}$ & \\
\hline
\end{tabular}

\subsection{Second Cycle}

Because unsatisfactory result in the first cycle on the students` improvement on the speaking skill, the researcher and the collaborator continue the research into the second cycle.

The data was analyzed by quantitative and qualitative data. The quantitative data were taken from the mean of student's score at writing descriptive text. The data were taken from a class which consisted of 22 students. The qualitative data were taken from interview, observation sheet, diary note and documentation.

This research was done in two cycle. Every cycle consisted of four steps of action research (plan, action, observation and reflection). Each cycle consisted of two meetings in this research.

\section{Quantitative Data}

The quantitative data were obtained from the score of student's writing test. The improvement of student's ability at writing descriptive text by using the learning cell learning strategy can be seen from the mean of student's score in pre-test, post-test in cycle I and post-test in cycle II.

The Student's Score in the Pre-Test

The researcher gave a test in the pre-test. The number of the students who test was 22 . Here the students score of pre-test as follow:

Table 2. The Student's Score in the Pre-Test

\begin{tabular}{lllll}
\hline No & Initial of Student & \multicolumn{2}{c}{ Pretest } \\
\cline { 3 - 5 } & & 55 & Score & Criteria Scores $(>75)$ \\
\hline 1 & Ais & 55 & Passed \\
2 & Dal & 62 & Failed \\
3 & Fat & 84 & Failed \\
4 & Fm & 60 & Passed \\
5 & Hjj & 62 & Failed \\
6 & Idn & 51 & Failed \\
7 & Jh & 53 & Failed \\
8 & Lf & & Failed
\end{tabular}




\begin{tabular}{clll}
9 & Mrd & 57 & Failed \\
10 & $\mathrm{Mh}$ & 73 & \\
11 & $\mathrm{Ma}$ & 37 & Failed \\
12 & $\mathrm{Na}$ & 68 & Failed \\
13 & $\mathrm{Nj}$ & 75 & Failed \\
14 & $\mathrm{Qrm}$ & 66 & Failed \\
15 & $\mathrm{Rh}$ & 37 & Failed \\
16 & $\mathrm{Rs}$ & 62 & Failed \\
17 & $\mathrm{Rn}$ & 75 & Failed \\
18 & $\mathrm{Rs}$ & 55 & Failed \\
19 & $\mathrm{Ygp}$ & 53 & Failed \\
20 & $\mathrm{Ya}$ & 62 & Failed \\
21 & $\mathrm{Ym}$ & 80 & Failed \\
\hline \multicolumn{2}{c}{ Total $\sum \quad x i=1282$} & & Passed
\end{tabular}

From the table of pre-test, the total score of students was 1282 and the number of students who took the test was 21 students, so the student's mean was:

$$
\begin{gathered}
\bar{x}=\frac{\sum \quad x i}{N} \\
\bar{x}=61.04
\end{gathered}
$$

From the analysis above, student's ability at writing descriptive text was low. The mean of students was 61.04. The number of students who were competent at writing descriptive text was calculated by applying the following formula :

$$
\begin{aligned}
& P 1=\frac{N 1}{N} \times 100 \% \\
& P 2=\frac{N 2}{N} \times 100 \%
\end{aligned}
$$

Table 3. The Percentage of student's Score in the Pre-Test

\begin{tabular}{clll}
\hline & Criteria & Total Students & Percentage \\
\hline P1 & Passed & 2 & $9,52 \%$ \\
P2 & Failed & 19 & $90,47 \%$ \\
Total & & & \\
\hline
\end{tabular}

From the table analysis, the student's ability at writing descriptive text was still low. The mean of students was 61,04 From the criteria 2 students got success score or it was only 9,52\% On the other one, 19 students got unsuccessful score or it was only $90,47 \%$ It could be concluded that the student's ability at writing descriptive text was still low when doing action research in pre-test. So, post-test continued in the first cycle.

The Student's Score in the Post-Test of the First Cycle

In the post-test of the first cycle, the data analysis can be followed bellow:

Table 4. The Student's Score in the Post-test of the First Cycle

\begin{tabular}{clll}
\hline No & Initial of Student & \multicolumn{2}{c}{ Pretest } \\
\cline { 3 - 4 } & & Score & Criteria Scores $(>75)$ \\
\hline 1 & Ais & 86 & Passed \\
2 & Dal & 66 & Failed \\
3 & Fat & 73 & Failed \\
4 & Fm & 86 & Passed \\
5 & Hjj & 71 & Failed \\
6 & Idn & 77 & Passed \\
7 & Jh & 71 & Failed \\
8 & Lf & 75 & Failed \\
9 & Mrd & 71 & Failed \\
10 & Mh & 80 & Passed \\
11 & Ma & 66 & Failed
\end{tabular}


International Journal of Social Science (IJSS)

Vol.1 No.2 August 2021, pp: 105-114

ISSN: 2798-3463 (Printed) | 2798-4079 (Online)

DOI: https://doi.org/10.53625/ijss.v1i2.143

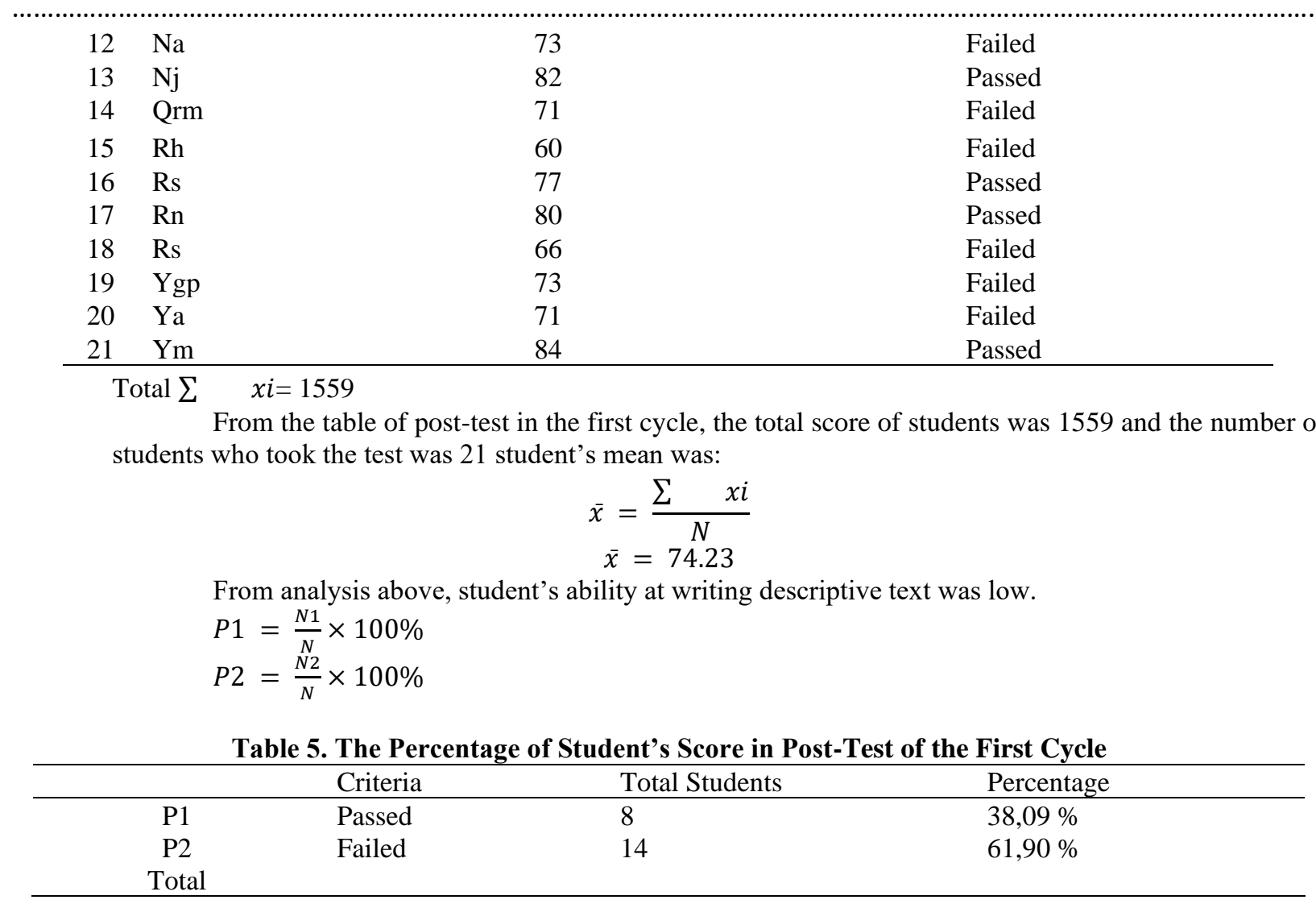

From the table analysis, the student's ability at writing descriptive text was still low. The mean of students was 74,23 From the criteria 8 students got success score or it was only $38,09 \%$. On the other one, 13 students got unsuccessful score or it was only $61,90 \%$. It could be concluded that the student's ability at writing descriptive text was still low when doing action research in post-test. So, post-test continued in the second cycle.

\section{The Student's Score in the Post-Test of Second Cycle}

The researcher gave test to the students in the end of each cycle. It was found that mean of student's score was kept improving from pre-test until post-test of the second cycle. The analysis of post-test in the second cycle as follow:

Table 6. The Student's Score in the Post-Test of Second Cycle

\begin{tabular}{clll}
\hline No & Initial of Student & \multicolumn{2}{c}{ Pretest } \\
\cline { 3 - 4 } & & Score & Criteria Scores $(>75)$ \\
\hline 1 & Ais & 95 & Passed \\
2 & Dal & 77 & Passed \\
3 & Fat & 80 & Passed \\
4 & Fm & 95 & Passed \\
5 & Hjj & 80 & Passed \\
6 & Idn & 82 & Passed \\
7 & Jh & 80 & Passed \\
8 & Lf & 82 & Passed \\
9 & Mrd & 86 & Passed \\
10 & Mh & 86 & Failed \\
11 & $\mathrm{Ma}$ & 73 & Passed \\
12 & $\mathrm{Na}$ & 80 & Passed \\
13 & $\mathrm{Nj}$ & 91 & Passed \\
14 & $\mathrm{Qrm}$ & 80 & Passed
\end{tabular}




\begin{tabular}{llll}
15 & Rh & 75 & Failed \\
16 & Rs & 86 & Passed \\
17 & Rn & 86 & Passed \\
18 & Rs & 77 & Passed \\
19 & Ygp & 77 & Passed \\
20 & Ya & 80 & Passed \\
21 & Ym & 91 & Passed \\
\hline
\end{tabular}

Total $\sum \quad x i=1739$

From the table of post-test in cycle II, the total score of students was 82,80 and the number of students who took the test was 21 student's mean was:

$$
\begin{gathered}
\bar{x}=\frac{\sum \quad x i}{N} \\
\bar{x}=82.80
\end{gathered}
$$

From analysis above, student's ability at writing descriptive text was low.

$$
\begin{aligned}
& P 1=\frac{N 1}{N} \times 100 \% \\
& P 2=\frac{N 2}{N} \times 100 \%
\end{aligned}
$$

Table 7. Percentage of student's Score in Post-Test of the Second Cycle

\begin{tabular}{clll}
\hline & Criteria & Total Students & Percentage \\
\hline P1 & Passed & 19 & $90,47 \%$ \\
P2 & Failed & 2 & $9,52 \%$ \\
Total & & & \\
\hline
\end{tabular}

From the table analysis, the mean of students was 82,80 From the criteria 19 students got success score or it was only $90,47 \%$. On the other one, 2 students got unsuccessful score or it was only $9,52 \%$. It could be concluded that the student's ability at writing descriptive text was improved. So, post-test of the second cycle was categorized success.

\subsection{The Improvement of the Student's Ability at writing Descriptive text by Using the Learning Cell Learning Strategy}

II.

Here the improvement of student's ability at writing descriptive text in the pre-test, post-test I and post-test

Table 8. Data Analysis of student's score in Pre-test, Post-test of the First Cycle, and Post-Test of the second Cycle

\begin{tabular}{cccccccc}
\hline No & Initial Of & \multicolumn{3}{c}{ Pre-Test } & \multicolumn{2}{c}{ Cycle 1 } & \multicolumn{2}{c}{ Cycle 2 } \\
\cline { 3 - 7 } & Students & Score & $\begin{array}{l}\text { Criteria } \\
\text { Success }\end{array}$ & Score & Criteria & Score & Criteria \\
& & Success & & Success \\
\hline 1 & Ais & 55 & Passed & 86 & Passed & 95 & Passed \\
2 & Dal & 55 & Failed & 66 & Failed & 77 & Passed \\
3 & Fat & 62 & Failed & 73 & Failed & 80 & Passed \\
4 & Fm & 84 & Passed & 86 & Passed & 95 & Passed \\
5 & Hjj & 60 & Failed & 71 & Failed & 80 & Passed \\
6 & Idn & 62 & Failed & 77 & Passed & 82 & Passed \\
7 & $\mathrm{Jh}$ & 51 & Failed & 71 & Failed & 80 & Passed \\
8 & $\mathrm{Lf}$ & 53 & Failed & 75 & Failed & 82 & Passed \\
9 & $\mathrm{Mrd}$ & 57 & Failed & 71 & Failed & 86 & Passed \\
10 & $\mathrm{Mh}$ & 73 & Failed & 80 & Passed & 86 & Passed \\
11 & $\mathrm{Ma}$ & 37 & Failed & 66 & Failed & 73 & Failed \\
12 & $\mathrm{Na}$ & 68 & Failed & 73 & Failed & 80 & Passed \\
13 & $\mathrm{Nj}$ & 75 & Failed & 82 & Passed & 91 & Passed \\
14 & $\mathrm{Qrm}$ & 66 & Failed & 71 & Failed & 80 & Passed \\
15 & $\mathrm{Rh}$ & 37 & Failed & 60 & Failed & 75 & Failed \\
16 & $\mathrm{Rs}$ & 62 & Failed & 77 & Failed & 86 & Passed \\
\hline
\end{tabular}


International Journal of Social Science (IJSS)

Vol.1 No.2 August 2021, pp: 105-114

ISSN: 2798-3463 (Printed) | 2798-4079 (Online)

DOI: https://doi.org/10.53625/ijss.v1i2.143

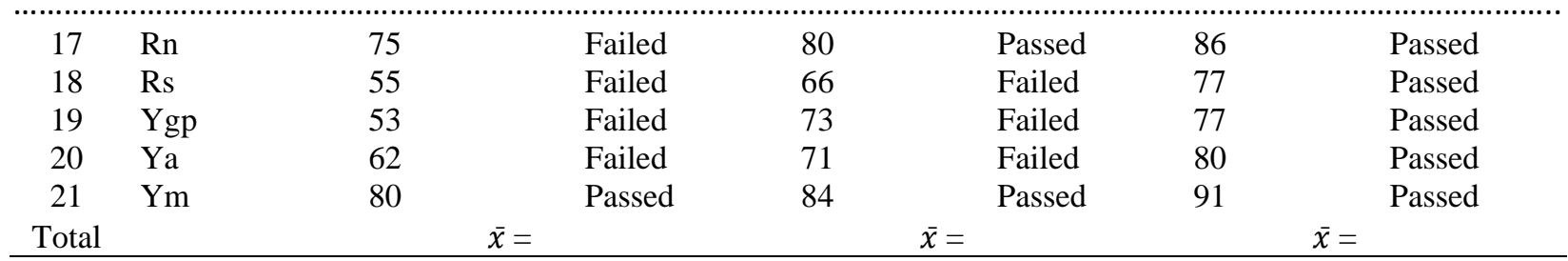

From the result of analysis showed that there was a development on the student's ability at writing descriptive text. It showed from the mean of pre-test was 61,04 , the mean of post-test in the first cycle was 74,23 , and the mean of post-test in the second cycle was 82,80 .

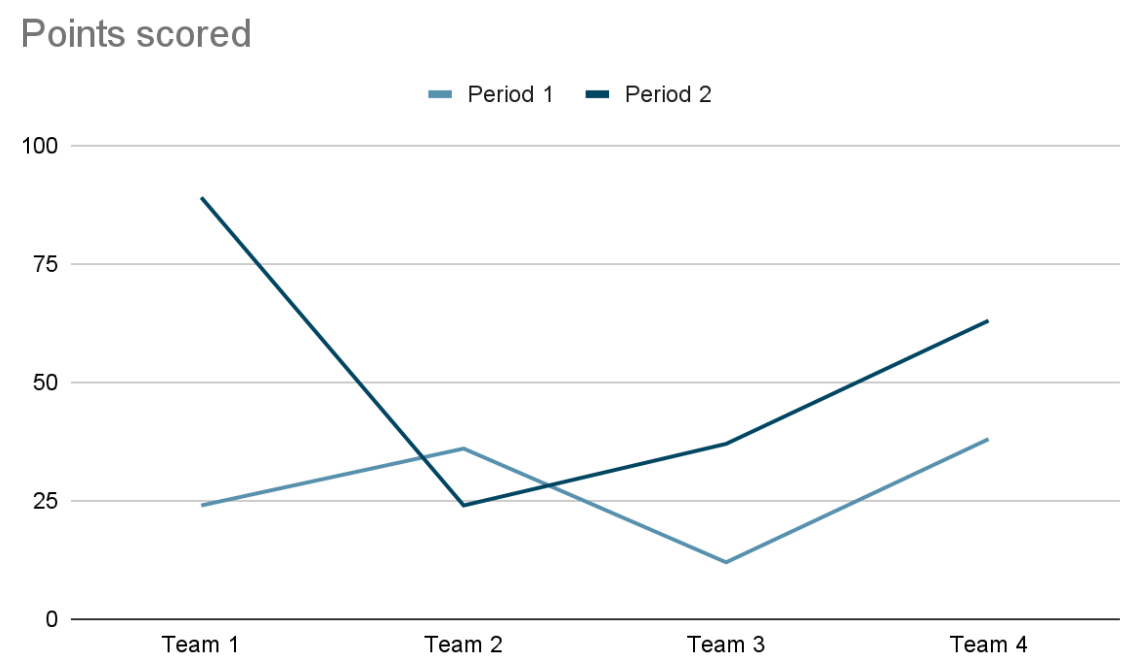

Table 9. The Percentage of Student's ability at Writing Descriptive Text by Using the Learning Cell Learning Strategy in Pre-test, Post-test I and Post-test II

\begin{tabular}{ccc}
\hline Meeting & $\begin{array}{c}\text { Student Who Get } \\
\text { Score }>75\end{array}$ & Percentage \\
\hline Pre-Test & \\
Cycle 1 & \\
Cycle 2 & \\
\hline
\end{tabular}

Based on the table above, the result of the analysis showed that there was an improvement on the student's ability at writing descriptive text. It was saw from the mean of pre-test was 61,04 , the mean of post-test in first cycle was 74, 23 and the mean of post-test in cycle II was 82,80. The percentage of the students score in pre-test who got point up to 75 there were only 2 of 21 students $(9,52 \%)$, and percentage of the student's score in the cycle I who got point up 75 there were only 8 of 21 students $(38,09 \%)$. It means that there was improvement about 28,57 $\%$. Then the percentage of the student's score in post-test of the second cycle who got point up 75 there were 19 of 21 students $(90,47 \%)$. It meant the improvement was $80,95 \%$.

The students score in pre-test, post-test I and post-test II had variation. In pre-test, the lowest score was 37 and the highest one was 84 . In post-test I, the lowest score was 60 and the highest score was 86 . In post-test II, the lowest score was 73 and the highest score was 95 . The comparison score of writing descriptive text s can be seen on the table below:

Table 10. The Comparison of the Student's Score in the Three writing Descriptive Text Test

\begin{tabular}{cccc}
\hline Name of Test & Pre-Test & Post-Test 1 & Post-Test 2 \\
\hline Lowest Score & & & \\
Highest Score & & \\
$\mathrm{R}$ (Range) & & \\
$\mathrm{N}$ & & \\
\hline
\end{tabular}




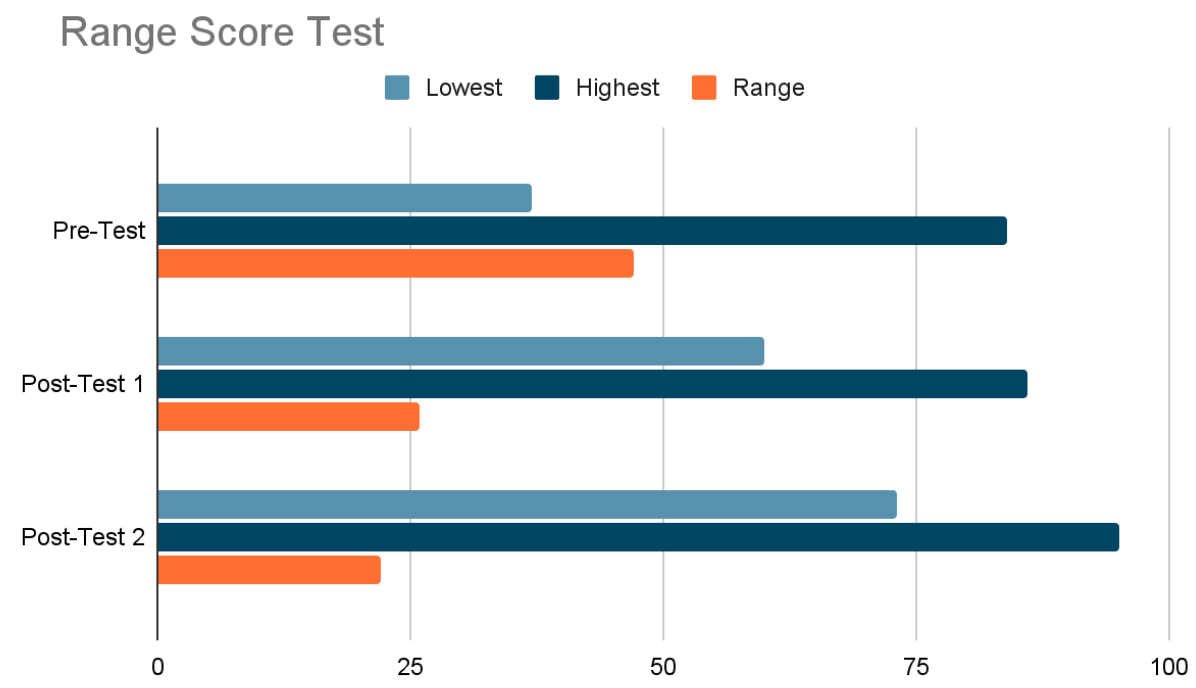

It concluded that the student's ability at writing descriptive text by using the learning cell learning strategy had increased from 61,04 to 82,80 .

\section{CONCLUSION}

Based on the result of the research, which aims to improve the student's ability at writing descriptive text by using the learning cell learning strategy, the researcher made conclusion related to the research question which are stated in chapter. The conclusions were obtaining through real phenomenon as the researcher did during the observation. The researcher draws some conclusion as follow:

The student's ability at writing descriptive text by using the learning cell learning strategy had improved. It could be showed from the discussion the result of pre-test and post-test in cycle I and II, the researcher could said that the learning cell learning strategy could be improved the student's ability at writing descriptive text. It is proved with student's improvement score of the tests because the mean of post-test in cycle I is higher than mean of pre-test $(74,23>61,04)$, the mean of post-test II in cycle II is higher than mean of post-test in Cycle I $(82,80>74,23)$. The proven target is $8,57 \%$ or 19 from 21 students who increase their writing descriptive text.

Observation and interview sheet result showed that the students were active, more enthusiastic and response during teaching learning process. Interview, observation sheet and documentation report showed that the learning cell learning strategy helped them at writing descriptive text.

\section{REFERENCES}

[1] A. Lunsford, Andrea. 2010. The St. Martin's Handbook Sixth Edition. R. R Donnelley \& Sons Company. New York.

[2] A. Mertles, Craig. 2014. Penelitian Tindakan Kelas. PT Indeks. Jakarta Barat.

[3] Al Hilali,Muhammad Taqi-ud-Din and Muhammad Muhsin khan (Post on October 06, 2003), The Noble Qur'an has been Translate into the odernEnglish Language.From ww.Alqur'an/EnglishTranslate.RetrivedFebruary 20, 2017 at 07.30 PM.

[4] Al-Tabany,TriantoIbnuBadar. 2014.Mendesain model pembelajaran inovatif,progresif dan kontekstual. Prenada Media Group. Jakarta.

[5] Ann Chin, Beverly. 2004. How to Write a Great Research Paper. Jhon Wiley \& Sons, Inc. Canada.

[6] Arikunto,Suharsimi.2013.Manajemen Penelitian. Rineka Cipta. Jakarta. Carrel, Joyce Amstrong. 2001. Writing and Grammar Communication and Action. Prentice Hall. America.

[7] Dewi, Utami.2013.How to Write.La-Tansa Press.Medan.

[8] Dirgeyasa.Wy. 2014. College Academic Writing: A Genre-Based Perspective.Unimed Press. Medan.

[9] Fajaryani, Sofi. 2015. The Use of Learning Cell to Improve Students Writing Skill on Hortatory Exposition Text in the Eleventh Grade Students of MAN I Magelang. Skripsi (pdf).FITK.PendidikanBahasaInggris. IAINSalatiga.From 5946142473. pdf.Retrieved February 20, 2017 at 09.30 PM.

[10] Istarani. 2012. 58 Model PembelajaranInovatif.Media Persada. Medan. 
International Journal of Social Science (IJSS)

Vol.1 No.2 August 2021, pp: 105-114

ISSN: 2798-3463 (Printed) | 2798-4079 (Online)

DOI: https://doi.org/10.53625/ijss.v1i2.143

[11] John.M. Echols and HasanShadly, Kamus Inggris Indonesia, Jakarta: PT Gramedia, 1996.

[12] Langan, (1985), College Writing Skill with Readings (Fifth Edition).McGraw Hill Companies. America.

[13] Muslich,Masnur.2010.Melaksanakan PTK(Penelitian Tindakan Kelas)itu Mudah.Bumi Aksara. Jakarta.

[14] Nunan, David. 2003. Practical English Teaching. McGraw Hill Companies.America.

[15] Rahman,KusdiantoKusuma(PostonApril28,2015).DefinitionandCharacteristic Writing Descriptive Text). From:http://www.idwrite.com/2015/04/definition-and-characteristic-of.html?m=1.Retrived January 27, 2017 at 09.27 PM.

[16] Silalahi,Ulber.2009.Metode Penelitian Sosial. PT Refika Aditama. Bandung. Siregar, Syofian. 2014. Statistik Parametrik Untuk Penelitian Kuantitatif. Bumi Aksara. Jakarta.

[17] Surjadi, A. 1989.Membuat Siswa Aktif Belajar. Mandar Maju. Bandung.

[18] Suryabrata,Sumadi. 2011.Metodologi Penelitian. PT Raja GrafindoPersada.Jakarta.

[19] Svinicki, Marilla and Wilbert McKeachie. 2011. Teaching Tips. WadsworthYusuf Cengage Learning. USA. LN, Syamsu. 2011. Psikologi Perkembangan Anak dan Remaja. PT Remaja Rosda karya

[20] R. Arulmozhiyal and K. Baskaran, "Implementation of a Fuzzy PI Controller for Speed Control of Induction Motors Using FPGA," Journal of Power Electronics, vol. 10, pp. 65-71, 2010.

[21] D. Zhang, et al., "Common Mode Circulating Current Control of Interleaved Three-Phase Two-Level VoltageSource Converters with Discontinuous Space-Vector Modulation," 2009 IEEE Energy Conversion Congress and Exposition, Vols 1-6, pp. 3906-3912, 2009.

[22] Z. Yinhai, et al., "A Novel SVPWM Modulation Scheme," in Applied Power Electronics Conference and Exposition, 2009. APEC 2009. Twenty-Fourth Annual IEEE, 2009, pp. 128-131. 
